Studies in African Linguistics

Volume 27, Number 2, Fall 1998

\title{
MAASAI GENDER IN TYPOLOGICAL PERSPECTIVE
}

\author{
Doris L. Payne \\ University of Oregon and Summer Institute of Linguistics
}

\begin{abstract}
Maasai nouns (or determined NPs) occur in one of three genders: masculine/ augmentative, feminine/diminutive, or place (the last is extremely limited). The Maasai gender system is semantic rather than formal (i.e., based on phonological or morphological criteria) in type, but with at least two distinct semantic subtypes. For a restricted set of nouns, gender is immutably based on lexical semantic features. Other nouns are lexically neutral, or have a default gender specification which can be overridden by the speaker's construal of the referent as small/ female, large/male, or pejorative. Varying by the noun, either of the productive genders may convey a pejorative construal, though it is most common in the feminine. The default gender of a noun is that which yields the non-pejorative sense. Some evidence suggests that feminine is becoming the grammatically unmarked gender.
\end{abstract}

\section{Introduction}

As citation forms, nearly all Maasai nouns carry a gender prefix. ${ }^{1}$ However, for the vast majority of common nouns, one can choose either the masculine or the

${ }^{1}$ Maasai includes perhaps as many as 20 relatively unstudied regional varieties. Maasai has been described as a variant of the Maa language, along with the Samburu and Camus dialects [Vossen 1988]. Maa belongs to the Eastern Nilotic family, and is spoken in Kenya and Tanzania. An earlier version of this paper was presented at the 29th Annual Conference on African Linguistics, New Haven, Connecticut [1998]. I am indebted to Leonard Kotikash and Robert Carlson for collaborative work on the structure of a Maa lexicography data base which led to this study, and to Morompi Ole-Ronkei, Renoi, and Kimeli Ole-Naiyomah (IlWuasinkishu Maasai), Leonard Kotikash and Philip Koitelel (IlKeekonyokie Maasai), Jonathan Ololoso (IlPurko Maasai), and Alejandro Bacaro for collaboration relevant to this project. I am grateful to Robert Carlson, Duke Allen, Austin Bush, Mitsuyo Hamaya, and Cynthia Schneider for conversations about Maasai lexicography; and to participants in a University of Oregon colloquium and to Immanuel Barshi, Robert Botne, Greville Corbett, Chet Crider, Gerrit Dimmendaal, Colette Grinevald, Tom Payne and Cynthia Schneider for their thoughtful comments on this paper. This research was partially supported by NSF grant SBR-9616482, a Fulbright research grant, and under Kenyan research permit \#OP/13/001/23C28. 
feminine gender prefix. The degree of flexibility in gender choice is quite striking if the language learner has background in a language type where a given noun root or stem is (generally) assigned to a specific, immutable, gender class. This contrast raises the question of a gender typology; that is, what is a gender system, and, what differing kinds of principles can drive gender systems?

According to Hockett [1958:231] and Corbett ([1991:1], who follows Hockett's lead), "genders are classes of nouns reflected in the behavior of associated words." That is, gender is not necessarily revealed in a noun word itself, but in other words in the phrase or sentence that co-occur with the noun. By this definition, Maasai clearly has two robust nominal gender classes and a third marginal class, which Tucker and Mpaayei [1955] term masculine, feminine, and place. Apparently only one noun root $w w e ́ j i$ 'place' belongs to the place gender; consequently, most of the discussion here will focus on the feminine and masculine genders. Gender-agreeing forms-in plain text in (1)—occur in the order feminine, masculine and place (the last seen in le and f only). ${ }^{2}$ Gender is manifested by prefixes on nouns (1a), but also in demonstratives which trigger omission of the nominal gender prefix (1b). It also surfaces in certain indefinite and possessive pronouns, relative clauses (1c), the genitive linker (which varies for gender of both possessor and possessed nouns; 1d), the singular interrogative pronouns for 'which' (1e), and agreement in certain numerals (1f; though adjectives do not show gender agreement) (cf. Tucker and Mpaayei [1955] from which most of the data in 1 are taken].

This paper seeks to determine the type of gender system found in Maasai. Although Corbett [1991] suggests that there are only two kinds of gender systems, "formal" and "semantic", I wish to investigate Maasai in terms of a richer typology of systems based on expansion of semantic subtypes, as in (2B, C, D). I will argue that the Maasai language generally is most accurately viewed
(1) a. en-kíné
ol-kíné
'goat, female goat'
'male goat'
b. Enâ kíné
'this (female) goat'
घlê kíné
'this male goat'
عlê ayyónì
'this boy'

2 The data appear in a modified form of Tucker and Mpaayei's [1955] orthography. Following Levergood [1987], I use $w w$ and $y y$ for the fortis or "strong" glides, rather than wu and $y i$; and $i, e, u, o$ (+ATR) and $\imath, \varepsilon, v, o(-\mathrm{ATR})$, instead of TM's system of non-bold versus bold script. Examples in this paper come from IIWuasinkishu Maasai (marked with $I I W$ ) and from the dialect found in TM (not marked in any way; in all the research I have so-far done, TM's data correspond to IlKeekonyokie Maasai). For this short paper, it is worth noting that lexical tone varies among dialects. Abbreviations are: CL classifier, F feminine, IIW IlWuasinkishu dialect, M masculine, pej pejorative, PL plural, SG singular, TM Tucker and Mpaayei [1955]. 
c. áínáí ná-ewwó

áínáí ó-ewwó

áínoว́naı náa-shomô

áíloónaı ว́ว-shomô
'Who (F.SG) has come?

It is who that has come?' (IlW)

'Who (M.SG) has come?

It is who that has come?' (IlW)

'Who (F.PL) have gone?

They are who that have gone?' (IlW)

'Who (M.PL) have gone?

They are who that have gone?' (IlW)

d. en-tókì $\varepsilon \quad n$-keráí. 'thing (F) of the child (F)'

en-tókì ó 1-ayyónì 'thing (F) of the boy (M)'

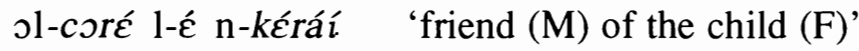

ol-coré 1-ó 1-ayyónì 'friend (M) of the boy (M)'

e. (k)álò

(k)áà

(k)ájì

f. Enk-olón nabô 'one day'

ol-tujánì obô

e-wwéjì nebô

Enk-ólònì aré

ıl-túnáná aárè

i-wwejítìn aré

'one place'

'two days'

'two men'

'two places' 'which (M.SG)'

'which (F.SG)'

'which (place)'

(2) A. Formal: gender is primarily based on phonological or morphological declension patterns

B. Lexical-semantic: gender transparently depends on lexical meaning of the noun root or stem

C. Referential-semantic: gender depends on features of the noun's intended referent

D. Cognitive-semantic: ${ }^{3}$ gender depends on speaker's construal of the intended referent

3 Or arguably cognitive-pragmatic; but as stated in Payne [1992:3], "In no way can a pragmatic account be usefully separated from a cognitive one, because the pragmatic acts are centrally concerned with ... the current cognitive status of information ..." 
as a combination of Types B and D. This is because there are "splits" in the vocabulary, such that some stems are best characterized as of Type B, but many stems are of Type D. In the course of demonstrating where Maasai belongs typologically, we will also address what the Maasai gender system reveals about grammaticalization and human cognition generally.

The "problem" of Maasai gender became particularly salient in the course of developing a lexicographic data base. Native speakers (almost) never give a noun root as a citation form, but always include a gender prefix. ${ }^{4}$ Thus, headwords in a dictionary for use by native speakers should be listed with some gender prefix. ${ }^{5}$ Tucker and Mpaayei's [1955] vocabulary recognizes this psycholinguistic issue and consistently lists whole word forms with some prefix. For example, it lists the feminine form en-kíné for 'goat', and gives the masculine form ol-natúny for 'lion'. However, both these roots can also occur with the opposite gender prefix: ol-kíné 'male goat' and e-natúny 'female lion'.

\section{Maasai gender within a typology of gender systems}

As noted previously, Corbett [1991] presents a broad two-way typology of gender systems, distinguishing "formal" gender systems (corresponding to Type 2A) from "semantic" gender systems. In a completely formal system (Type A), determination of what gender class a noun belongs to depends on issues of form. This may be either morphological declension patterns, or phonological form. Corbett notes that even formal morphological systems always have some semantic core, but gender assignment does not depend on meaning in any reliable way. In contrast to Type A, Corbett defines a "strict semantic" gender system as one "in which the meaning of a noun determines its gender and in which, equally, given the gender of a noun we can infer something about its meaning" [allowing for very occasional exceptions; Corbett 1991: 8, 13]. As stated, this arguably describes a Type B gender system. Corbett offers Tamil and other Dravidian languages, Diyari (Australian), Dizi (Omotic), Defaka (Afakani from South Central Niger-Congo), and English pronouns as examples. A "predominantly semantic" gender system is one which allows even more exceptions, perhaps with a proliferation of gender subclasses and some "semantic residue" [Corbett 1991:13]; but the unpredictable assignment of a

4 There are a few exceptional roots which never take a gender prefix, such as the root kulé 'milks' (collective kúliárêi); that this root has lexically-specified feminine gender is shown by demon-strative and other agreement forms parallel to those given in (1). Other exceptions include some (primarily) vocative nouns like yyeyyô 'mother'. Gerrit Dimmendaal (personal communication) suggests that it may be something of a typological anomaly for the nouns to carry grammatical gender since Maasai personal pronouns do not distinguish gender.

5 Dictionary entries for nouns are further complicated by the fact that Maa nouns have to be specified for one of 12 to 16 very irregular singular-plural classes, and for one of about 4 tone classes for tonal case marking. 
noun to a gender is still very occasional, and often historically comprehensible. Here I suggest we can usefully expand the exploration of semantic types into three options, distinguishing what I have called Types B, C, and D in (2) above.

Gender Types A and B both assume, if not require, that the noun root is lexically-specified for specific features which determine gender. Around the world, the major semantic features that surface as bases for strictly or predominately semantic gender systems are listed in (3) [cf. Corbett 1991, de la Grasserie 1898]. Some languages rather transparently proliferate gender distinctions for insects, hunting tools, pets, edible items, liquids, etc. [and the systems concomitantly begin to approach what are termed "noun class" or "noun classifier" systems; cf. Craig 1986].

(3) Common features in semantic gender systems

animate - inanimate, human — non-human, rational —non-rational, male-female, male-other, female-other, strong-weak,

augmentative -diminutive

In a formal system, Corbett notes that there is always a semantic core; but synchronically, assignment to a particular gender is often not semantically transparent. In a formal system (A), the lexical items would carry grammatical specification of gender features, like [+FEM gender]. If formal gender is predictable from phonological form, what the speaker memorizes for each form is, of course, the phonology, combined with the general rule of how to predict gender from the lexical phonological forms. In a lexical semantic system (B), by contrast, gender assignment is much more transparent, being dependent on lexical semantic features like [+biologically female], [+edible fruit] if edible fruits predictably all belonged to a certain gender; or [+small] if all items with the lexical feature of [+small] belonged to a certain gender. But in either case, the relevant features are indicated in the lexicon, i.e., they are part of what a speaker must simply memorize about the lexical form.

Types C and D, like Type B, are also semantically-grounded. However, Types $\mathrm{C}$ and $\mathrm{D}$ are of an opposite extreme in that gender assignment can be determined during "on line" processing while the speaker is accessing or conceptualizing potential referents. That is, noun roots or stems are not associated with any particular grammatical gender in the lexicon.

Indo-European gender systems are predominantly of Type A. In Spanish, for example, most noun roots or stems are either grammatically masculine or feminine, and a second-language learner must to a great extent simply memorize the gender of each word. The gender of a given word can be quite reasonably predicted by whether a noun ends in /a/ (typically feminine) versus /o/ (typically masculine), and a few other somewhat predictive morphophonological endings. But phonology is not a fool-proof determinant of Spanish gender. Rather, gender is decisively revealed by the agreement patterns found in co-occurring 
articles, demonstratives, and adjectives. For a very small sample, observe the potential noun forms in (4). The feminine noun roots have no masculine counterpart (4a); while the masculine ones have no feminine counterpart (4b). 6 The forms in (5) appear to be simply homophones; that is, the roots in the two columns are instances of different roots. They thus do not compare to the Maasai situation which we will consider shortly.

(4)

a. GRAMMATICALLY FEMININE mujer 'woman'

vaca

goma

mesa 'cow' 'gum, rubber' 'table'

luna 'moon'

gramática 'grammar' coronación 'coronation'

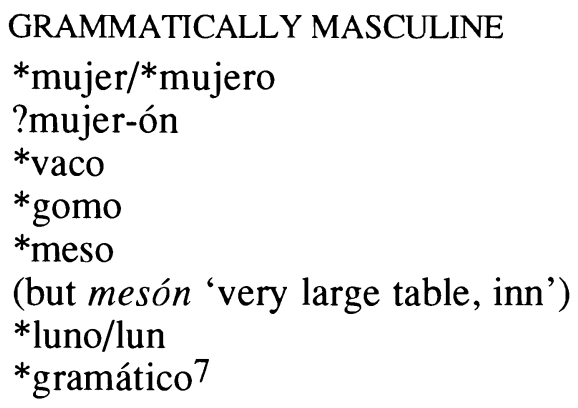

GRAMMATICALLY MASCULINE *mujer/*mujero

?mujer-ón

*vaco

* gomo

*meso

(but mesón 'very large table, inn')

*luno/lun

* gramático 7

b. GRAMMATICALLY FEMININE

* rostra

*techa

*ciela

*sola

*problemo

*tora

(5)

$\begin{array}{ll}\text { la papa } & \text { 'potato' } \\ \text { la plaza } & \text { 'plaza' } \\ \text { la caballa } & \text { 'mackerel' }\end{array}$

GRAMMATICALLY MASCULINE

$\begin{array}{ll}\text { rostro } & \text { 'countenance, face' } \\ \text { techo } & \text { 'roof' } \\ \text { cielo } & \text { 'sky, heavens' } \\ \text { sol } & \text { 'sun' } \\ \text { problema } & \text { 'problem' } \\ \text { corazón } & \text { 'heart' } \\ \text { toro } & \text { 'bull' }\end{array}$

The starred forms in (4) do not negate the fact that some Spanish roots can occur with either a feminine (typically $-a$ ) or a masculine (typically $-o$ ) ending. The alternation sometimes corresponds to biological gender, demonstrated in (6); these roots are thus arguably like those in Maasai examples (1a) and (8) below.

6 I am grateful to Alejandro Bacaro, a speaker of El Salvadorian Spanish, for the grammaticality judgments and meanings listed here. As is to be expected, there is some dialectal variation such that mujerón might be acceptable for speakers of some other dialects.

7 The masculine Spanish word gramático occurs as an adjective, but not as a noun. 
(6) GRAMMATICALLY FEMININE

$\begin{array}{ll}\text { muchach-a } & \text { 'little girl' } \\ \text { gat- } a & \text { 'female cat' } \\ \text { leon- } a & \text { 'female lion' }\end{array}$

GRAMMATICALLY MASCULINE

muchach-o 'little boy'

gat-o

león 'male cat'

'male lion'

One might thus argue that Spanish roots which refer to biologically animate items, as in (6), demonstrate a semantically-based Type C or D system where roots are not lexically-specified for gender. However, we have already seen that this is not entirely true, given immutably feminine roots like mujer 'woman', vaca 'cow', yegua 'mare', and strictly masculine roots like toro 'bull' and caballo 'horse.' These roots are rather clearly lexically specified for gender, arguably according to a Type B system.

There are yet other Spanish roots which can switch gender, where the grammatical gender specification cannot depend on biological reference (7). Here the grammatical gender alternation corresponds to a rather large meaning change, characteristic of derivational morphology. The alternation does not always have a predictable semantic correlate (e.g., biological gender or size), so it is still best to conclude that gender must be lexically marked at the stem, if not the root, level.

(7) GRAMMATICALLY FEMININE

leñ- $a$ 'firewood, sticks'

cosech-a 'crop, harvest'

grad-a

papeler-a 'waste bin'

explosiv-a 'plosive consonant'

vinaza

pisa

vid

manzana 'wine from the dregs'

'treading (of grapes)'

'vine'

'apple (fruit)'
GRAMMATICALLY MASCULINE

leñ-o 'log, timber'

cosech-ón 'bumper crop'

grad-o

papeler-o

'degree, stage, measure; quality'

'man who makes paper; mess of papers in office; Mex: 'paper-boy'

explosiv-o 'explosive (chemical)'

vinazo

piso

vino

manzano 'strong wine'

'floor'

'wine'

'apple tree'

Initial work on Maasai led to the impression that, in contrast to the IndoEuropean type, the vast majority of Maasai noun roots can occur with either a feminine or a masculine prefix. For roots of the type in (8a), one might initially assume that the gender-prefix depends generally on whether the entity referenced is biologically feminine or masculine, and that thus these data are exactly like the Spanish in (6) and (7). But this is not true throughout the lexicon, as seen in the (8b) roots anáshè 'sister', títo 'girl', and aláshè 'brother' where the gender prefix varies but the biological gender does not. (Some speakers reject the $\varepsilon n k a l a ́ s h \varepsilon$ variant in (8b) while others from the same region more flexibly 
allow it).

(8) (all from $I l W$ )

a. changes in biological gender

FEMININE PREFIX

Enk-aputánì 'wife's female parent'

Enk-aırrítànì 'herdswoman, small herdsman'

en-kitók 'woman'

Enk-abáánì 'female or small doctor, quack'
MASCULINE PREFIX

ol-aputánì 'wife's male parent'

ol-aurrítànì 'herdsman'

ol-kitók 'very respected man'

ol-abáánì 'male doctor, healer'

b. changes in size and denigration

FEMININE PREFIX

Enk-anáshè 'sister'

en-títo 'girl'

Enk-aláshè 'weak brother' (pej)

عnk-ámùyc̀ 'wimpy male donkey'
MASCULINE PREFIX

olk-anáshè 'very large sister' (pej)

ol-títo 'large shapeless hulk of a woman' (pej)

ol-aláshè 'brother'

ol-ámùyè 'male donkey'

The Maasai gender alternation extends beyond such roots to lexemes for inanimate entities that also fluidly occur in both feminine and masculine forms. As the data in (9) show, the feminine gender can also indicate items which are construed as diminutive or pejorative (e.g., degraded, worthless, obnoxious). The masculine gender can reference an item which is biologically masculine, or augmentative (and also sometimes pejorative, though this seems less frequent than with the feminine gender; cf. olk-anáshè 'very large sister' in (8) above) ${ }^{8}$

The Maasai examples in (8-9) might initially suggest that Maasai gender combines the semantic features of male+augmentative and female+diminutive features into something like a Type B system (see 3), and that Maasai, at least, does not force any typological elaboration beyond a distinction between Types A and B. However, a careful examination of language use, plus careful reading of Corbett's own examples and discussion (cf. references to Mathiot and Roberts [1979]; Svartengren [1927]) suggest that even for a strictly or predominantly semantic system, Corbett does not literally, or only, intend that the inherent lexical semantic features of a noun, divorced from any particular context of use, are what always determine gender assignment. The possibility of different class (gender) assignments in different contexts has been argued for classifier choice

8 A reviewer has suggested that although grammatical gender is explicitly marked in Maasai, there is no explicit marking of denigration; that is, denigration may be more pragmatic, or less completely "semanticized", than is gender. 
(9) (all from $I l W$ )

\begin{tabular}{|c|c|c|c|}
\hline \multicolumn{2}{|c|}{ FEMININE PREFIX } & \multicolumn{2}{|c|}{ MASCULINE PREFIX } \\
\hline عn-dóínyó & 'hill' & ol-dóinyó & 'mountain' \\
\hline En-kalámù & 'pen, pencil’' & ol-kalámù & ‘large pen, pencil’ \\
\hline Enk-abobókì & $\begin{array}{l}\text { 'tree bark, small piece } \\
\text { of bark' }\end{array}$ & ol-kabobókì & 'huge piece of bark' \\
\hline en-keráí & ‘child’ (either sex) & ol-keráí & 'large, masc child' \\
\hline Enk-álém & 'knife' & ol-álém & 'sword' \\
\hline عnk-áré & 'water, river' & ol-áré & 'salt water' \\
\hline E-sílígí & $\begin{array}{l}\text { 'weak, vain? faith' } \\
\text { (humorous) }\end{array}$ & o-sílígí & 'hope’' \\
\hline عm-bác̀ & $\begin{array}{l}\text { 'arrow, matter, affair; } \\
\text { tiny injury' (in right } \\
\text { context) }\end{array}$ & ol-bác & $\begin{array}{l}\text { 'large arrow; opinion; } \\
\text { wound, injury' }\end{array}$ \\
\hline
\end{tabular}

(which is typologically connected to gender) in many languages [Craig 1986; Denny 1976]. The data in (10) from Amarakaeri (Peru) illustrate the point, all involving a single root siro 'metal, glass, plastic, machete'. That is, if the lexical semantic features of noun roots determined classifier choice, we should expect that for any one (sense of a) noun, one and only one classifier should be grammatical with the root. However, depending on exactly what the speaker wants to reference (and not on the root itself), one classifier versus another can be chosen. Arguments that the suffixal morphemes in (10) are grammatically classifiers are based on their incorporability into verbs to reference absolutive arguments [Hart 1963, Payne 1987:37].

(10) Amarakaeri classifying morphemes

$\begin{array}{ll}\text { siro } & \text { 'metal, glass, plastic, machete' } \\ \text { siro-pa (CL:rod) } & \text { 'large nail, metal rod' } \\ \text { siro-pu' (CL:tube) } & \text { 'glass bottle, metal tube' } \\ \text { siro-' in (CL:tooth) } & \text { 'fishhook' } \\ \text { siro-pi (CL:stick) } & \text { 'small nail, needle' } \\ \text { siro-po (CL:round) } & \text { 'tin can' } \\ \text { siro-mih (CL:string-like) } & \text { 'wire, plastic fish line' } \\ \text { siro-kmo (CL:seed-like) } & \text { 'shotgun shot' }\end{array}$

In sum, in a Type $\mathrm{C}$ referential-semantic system it would be the (set of) item(s) referred to within the universe of discourse-and not the particular noun used-that determines gender assignment. To see this with a specific Maasai example, consider the root aputánì which, in and of itself, means 'wife's parent' (see 8 above). No lexical semantic feature of this root enables us to 
predict what gender assignment will surface. Rather, depending on whether the referent is the wife's mother or the wife's father, either $\varepsilon n k$-aputánì or $\$ 1$ aputánì will surface. We thus conclude that to completely account for gender assignment in Maasai (and in Spanish), assigning all roots or stems to either Type A or Type B would be insufficient; we must add Type C.

However, careful consideration of the Maasai gender system suggests that, ultimately, it is not even features of the referenced entity that determine gender (or classifier) choice in primarily semantic systems. Much more precisely, it is the speaker's cognitive construal of a referent (Type D). That is, whether an Amarakaeri speaker wishes to reference one and the same item as a siro-pa 'large nail, metal rod' versus a siro-pi 'small nail, needle' depends on how the speaker chooses to conceptualize or construe that item on any given occasion. This basis for gender assignment is also acknowledged in Corbett's discussion when he notes that the "straightforward semantic rules" governing use of English pronoun forms like he, she, it can be "overridden by emotive and affective factors" [p. 12]. Corbett does not particularly elaborate what "emotive and affective factors" are, but what I intend by a Type D system is that the speaker can, from one occasion to another, change the way even the same referent token is conceptualized relative to the features comprising the gender (or classifier) system - all the while still cognizing it as the same referent. As a consequence, the speaker may vary the choice of grammatical gender prefix. From this perspective, I suggest that Type $\mathrm{C}$ systems are in fact spurious and do not exist at all, as it is always the speaker's construal or cognitive conceptualization of a referent that matters-and not the ostensibly-objective referent in and of itself. ${ }^{9}$ For Maasai, the pejorative sense that sometimes arises with one versus another gender choice also points to the fact that it is neither features inherent to the lexical meaning of the root (Type B), nor features of the referent (Type $C$ ) that are (always) determinative of gender specification because in referencing one and the same token item, a given speaker may sometimes intend derogation, but other times, not.

I hope to have thus established that a comprehensive gender typology must include languages (or lexical items within a language) that are of Type D. Turning now, however, to a comprehensive understanding of Maasai, there is good evidence that the language as a whole, i.e., lexical items within the language, are split between Types B and D. There are three types of evidence supporting the claim that some lexical items are of Type B. There are some noun stems whose only allowable lexical gender assignment is [+FEM]; many fewer are strictly [+MASC]. Others have a default assignment of [+FEM] or of [+MASC], but this can be over-ridden by Type D considerations. Finally, some

9 With regard to a different domain of grammar, I have similarly reasoned elsewhere that constituent order is likely never based on pure semantic roles, but either on grammatical phenomena (e.g., grammatical relations) or on cognitive-pragmatic construal [Payne 1992:3]. 
roots may be genuinely neutral for lexical gender specification and their assignment on any occasion of use may be strictly based on Type D factors. We will consider each of these lexical subtypes in turn.

\section{Maasai lexical subclasses}

3.1 Immutable Type B lexemes. Despite the impression that Maasai vocabulary is highly "fluid" in terms of ability to take both feminine and masculine gender prefixes depending on cognitive construal of the referent, it turns out that there are some lexical stems which can only occur in feminine gender form. Some of these appear to be basic roots. The roots in (11a) apparently cannot take masculine prefixes under any possible construal. My current assessment is that such roots comprise a fairly small set.

\section{(11) a. FIXED FEMININE GENDER}

(ungrammatical if masculine prefix occurs; $I l W \& \mathrm{TM}$ )

$\begin{array}{ll}\text { enk-áí } & \text { 'God' } \\ \text { en-kirinó } & \text { 'meat' } \\ \text { kulé } & \text { 'milks' }\end{array}$

kulé 'milks' (collective, which does not take a gender prefix but triggers feminine agreement in determiners, relative clauses, etc.)

En-kímá 'fire' (compare Enkímá sápúk 'big fire’)

b. FIXED MASCULINE GENDER (for some $I l W$ speakers; compare $8 \mathrm{~b}$ ) ol-aláshè 'brother'; *Enk-aláshè

One might speculate that roots like those in (11a) evidence the beginning of a formal Type A lexical subset, because what inherent lexical semantic features might drive the feminine assignment are, to western conceptualizations, arguably opaque. That is, there is nothing like a [+diminutive] or obvious [+biologically feminine] lexical feature to drive feminine gender assignment. From an historical perspective, this is probably premature and the set merits examination from the perspective of African cultural models, and propositional or concept association, metonymic, metaphoric, important property, and image-schematic models as described by Lakoff [1986] and Corbett [1991]. For instance, in certain other African cultures such as Akan the concept of the supreme deity is feminine (cf. Osam [n.d.]); and concept association (or knowledge-network) association between feminine biological gender and milk is obvious.

Other items with fixed and immutable feminine gender are certain types of nominalizations. Though exploration of nominalizations is in its infancy, perusal of Tucker and Mpaayei's grammar and some elicitation suggests that the 
nominalization types in (12-14) are strictly feminine; switching them to masculine gender results in ungrammaticality.

(12) Action nominalizations in -ata (-oto)

enk-írúkótó 'belief' (from a-irúk 'to believe, obey, answer when addressed')

Em-búátá 'extraction' (from a-búá 'to have incisor teeth taken out'; $a-b$ ' 'to extract incisor teeth')

(13) Action nominalizations in -are (-ore)

E-míshíràrè 'branding' (from a-mishír 'to brand')

e-lómórè 'acting jealous' (a-lóm'to be jealous' cf. 16 below)

en-jútórè 'erasing' (a-jút 'to rub, wipe, erase')

(14) Stative nominalizations in -an (-on)

E-rokán 'blackness' (a-rok 'to be black')

(15) Other strictly feminine nominalizations

\begin{tabular}{|c|c|c|}
\hline En-dálà & 'game' & (edálárè 'he/she plays') \\
\hline Enk-ányìt & 'respect' & (a-anyít'to respect') \\
\hline$\varepsilon$-modâ & 'foolishness' & (a-modá 'be dull-witted') \\
\hline En-kıtoríá & 'rule' & (a-ıtoré 'to rule') \\
\hline$\varepsilon$-nanầ & 'softness, tenderness' & (a-naná 'to be soft') \\
\hline cn-kıbál? sl-kıbá & 'hate' & (a-l.bá 'to hate') \\
\hline
\end{tabular}

For the most part, these are abstract nominalizations. The fact that such abstract terms are placed into the feminine category suggests that feminine is the unmarked gender in Maasai. 10 This still fits with Corbett's characterization of a primarily semantic gender system in that "other" or [+abstract] items are assigned to the default gender.

There are a few abstract nouns/nominalizations (16) which appear to be exclusively masculine in designation. An inherent semantic feature of the verb roots in (16) is that they designate negative concepts. Though it needs further investigation, we might speculate that an inherent negative feature is what partially obviates any motivation to switch them to a feminine form in order to yield a pejorative meaning. That is, "pejorative jealousy" or "pejorative con-

10 The fact that feminine gender more frequently seems to convey denigration might argue against feminine as being somehow semantically unmarked. However, the fact that borrowings and most abstract nominalizations are placed in the feminine category suggest that feminine is grammatically unmarked. 
tempt" is redundant if not meaningless. (As we will see below, there are some other abstract nominalizations which seem to have a default masculine form, but which can be over-ridden with the feminine form to derive a pejorative sense.)
(16) o-lôm
'jealousy, envy' ?E-lôm 11
(a-lóm 'to be jealous')
ol-mená
'contempt'
*E-mená
(a-men 'to despise')

3.2 Variable Type B lexemes. In Section 2, I appealed to the surfacing of pejorative meanings as evidence that Maasai has a Type D gender system. Without obviating the conclusion from that argument, it is simultaneously the case that the pejorative phenomenon also gives evidence that some Maasai stems are of Type B in having a default lexical gender assignment; it is just that for a certain class of Type B stems, the default assignment can be over-ridden by Type D factors.

We have seen that some speakers allow the feminine gender prefix with a sense of pejorativeness for nouns whose unmarked prefix (perhaps in a statistical sense) is masculine, particularly if the root references a biologically animate entity. Since most roots referencing such entities are not in themselves pejorative, it suggests that whatever gender prefix causes retention of the nonpejorative meaning is the unmarked gender assignation for the root in question; while a gender prefix giving rise to a pejorative sense is the marked choice for the root in question. It then further follows that at least for the class of roots where pejorative senses can arise with one gender choice, there is also a lexically-specified unmarked gender choice. Thus, at least these roots belong to a Type B gender system, which a Type D marked construal can override.

For specific examples, consider (17-18). The noun stems themselves (minus the prefixes) do not have any particularly pejorative lexical semantic feature. This lack of pejorative meaning is retained with one gender assignment, which must be the default lexical gender assignment for the stem in question. The fact that a pejorative meaning arises with the opposite gender designation suggests that opposite gender is the marked gender for the stem in question. This default/ markedness difference must be part of the lexical information about the root or stem. Note that sometimes the unmarked gender is feminine, and sometimes masculine-to some extent (though not fully) predictable on the basis of lexical biological gender meaning features.

(17) Default feminine gender assignment

$\begin{array}{llll}\begin{array}{l}\text { Enk-anáshè } \\ \text { en-títo }\end{array} & \begin{array}{l}\text { 'sister' } \\ \text { 'girl' }\end{array} & \begin{array}{l}\text { olk-anáshè } \\ \text { ol-títo }\end{array} & \begin{array}{l}\text { 'very large sister' (pej) } \\ \text { 'large shapeless hulk of a woman' } \\ (p e j)\end{array}\end{array}$

11 One IlWuasinkishu speaker suggests that enk-óm and enk-ómórè would be possible pejorative forms for 'jealousy', with the latter more likely than the former; clôm was firmly rejected. 
(18) Default masculine gender assignment

\begin{tabular}{|c|c|c|c|}
\hline ol-aláshè & 'brother' & Enk-aláshè & 'weak brother' (pej) \\
\hline o-léع & 'man' & $\varepsilon$-lé $\varepsilon$ & $‘ \operatorname{man} ’(p e j)$ \\
\hline -órj̀ & 'he-goat, ram' & Enk-órò & 'small he-goat' (or $p$ \\
\hline -payyán & $\begin{array}{l}\text { 'elder' (only men } \\
\text { past warriorhood) }\end{array}$ & em-payyán & ‘elder’ (pej) \\
\hline l-abáánì & $\begin{array}{l}\text { 'male doctor, } \\
\text { healer' } \\
\text { (from a-bák 'to heal') }\end{array}$ & Enk-abáánì & $\begin{array}{l}\text { 'female/small doctor, } \\
\text { quack (pej)' }\end{array}$ \\
\hline rámátèì & $\begin{array}{l}\text { 'nurturing' } \\
\text { (from a-ramát } \\
\text { 'to nurture')12 }\end{array}$ & E-rámátèì & ‘nurturing (pej) \\
\hline -míshíré & $\begin{array}{l}\text { 'brand mark/iron' } \\
\text { (from a-mishír } \\
\text { 'to brand') }\end{array}$ & E-míshíré & 'malfunctioning iron' \\
\hline dekśt & $\begin{array}{l}\text { 'curse' } \\
\text { (from a-dék 'to curse') }\end{array}$ & $\varepsilon n-d \varepsilon k \varepsilon ́ t$ & 'ineffectual curse' \\
\hline
\end{tabular}

While abstract concepts are generally fixed in their gender assignments, we note that some abstract nominalizations follow this "Default Type B" pattern. Nominalizations which refer to concrete objects more flexibly occur in either gender, though with pejorative meaning common for the feminine grammatical gender. Other times there is no particular pejorative sense to the feminine, as in the nominalization en-jutét 'eraser', ol-jutét 'big eraser' (from a-jút 'to rub, wipe, erase'). ${ }^{13}$ If the unmarked form is masculine and the lexemic concept is already inherently pejorative or negative, it appears that the feminine prefix cannot occur (16).

Work on gender of borrowings is in its infancy, but current information also suggests that the default gender assignment for borrowings is feminine: embúkù 'book'. Since the term em-búkù 'book' refers to a concrete object, one can say ol-búkù to refer to a book that is construed as very large. However, the apparently default assignment of borrowings to the feminine category provides further support for the claim that feminine gender is unmarked in Maasai.14

$12 \mathrm{TM}$ list the nominalization as meaning 'cattle culture.' But for IlWuasinkishu, the nominalization appears to be better translated as 'take care of' (and can be applied to cattle, children, books, etc.)

13 It might be argued that the default lexical specification for jutét is feminine because the masculine form has an extra [+augmented] feature (see also examples in 9). However, it is not entirely clear to me whether any sense of an "extra" feature is just an artifact of the English translation, and whether such stems should be best viewed as of Type D.

14 In further support of the unmarked status of the feminine gender, Gerrit Dimmendaal (personal communication) has pointed out that in simple Maasai sentences like 'What is this?', 
Like Maasai, Dizi (Omotic, Ethiopia) also has a two-class gender system combining feminine + diminutive, as opposed to masculine (or, we might suggest, other). But unlike Maasai, most nouns in Dizi end up in the masculine class as the default for anything that is not female or diminutive [Corbett 1992:11]; according to Corbett, gender assignment is still predictable according to the natural features of the referent. 15

3.3 Neutral Type D lexemes. Finally, there are numerous roots and stems which can occur with either gender prefix, with no particular pejorative or extra marked features arising from either designation. To the extent that this is true, such roots/stems have no default lexical gender designation, and the root itself must be classified as strictly of Type D. Agent nominalizations in -anì are typically included in this category (though see $s l$-abáánì 'male doctor, healer' versus Enk-abáánì 'female/small doctor, quack (pej)’ above).

(19) (tone from $I l W$ )

\begin{tabular}{|c|c|c|c|}
\hline enk-aputánì & 'wife's fm. parent' & sl-aputánì & 'wife's male parent' \\
\hline E-modáí & 'a female fool' & ol-módáí & $\begin{array}{l}\text { 'a male fool' (from } \\
\text { a-modá 'be dull-witted') }\end{array}$ \\
\hline & 'sheep' & $o l-k$ & 'castrated ram'16 \\
\hline & 'cow, head of cattle & ol-kítén & 'ox' \\
\hline
\end{tabular}

\section{Conclusions}

Corbett suggests that despite the seeming naturalness of pure semantic gender systems, they are not particularly common. Languages quickly develop idiosyncrasies via conceptual analogies, metaphorical extension, borrowing, and encroaching lexicalization, and eventually gender of noun roots must simply be learned. I have suggested there may be more than one type of "strict" or "predominately semantic" gender system: Types B and D. (Type C is obviated by $\mathrm{D}$ on general philosophical and cognitive grounds.) At present, many (perhaps most) Maasai roots display a Type D system. This likely goes hand-in-hand with the fact that Maasai inflectional gender is relatively new in a historical

the correct demonstrative to use is the feminine one. Dimmendaal also notes that Vossen [1988] reconstructs approximately twice as many feminine gender nouns than as masculine gender nouns for Proto-Teso-Turkana-Lotuxo-Maa.

15 Though Dizi is a predominantly semantic system, Corbett says "It is worth noting that feminine nouns [in Dizi] can also be identified formally, since they have the suffix -e or -in": dade 'girl,' kuocin 'woman,' wete 'cow,' kieme 'small pot,' orce 'small broom.' Compare: dad 'boy,' yaaba 'man,' kiemu 'pot,' orca 'broom.' Halkomelem (Salish) is also similar to Dizi and Maasai in grouping feminine and diminutives into one class.

16 'Ram' itself is expressed by either ol-órj̀ or ol-mérègèsh. 
sense. Inflectional gender is not found in Nilotic generally, but does occur within the Eastern Nilotic sub-branch.

Nevertheless, for at least some Maasai roots (or stems) there is a specific, or unmarked lexical specification of either masculine gender (e.g., those roots which by their inherent lexical features normally reference biologically masculine entities, some abstract nominalizations) or feminine gender (e.g., those roots which by their inherent lexical features normally reference biologically feminine entities, many abstract nominalizations). Whenever a pejorative sense arises with a gender choice for a root, it gives evidence that the non-pejorative gender is lexically unmarked for that root. Such roots display a Type B system. However, Maasai gender is not fully lexicalized because to a very great extent speakers are free to over-ride the lexically unmarked gender under a Type D construal.

\section{REFERENCES}

Corbett, Greville. 1991. Gender. Cambridge: Cambridge University Press.

Craig, Colette (ed.). 1986. Noun Classes and Categorization. Amsterdam: John Benjamins.

Denny, J. Peter. 1976. "What are noun classifiers good for?" Chicago Linguistics Society 12:122-132.

de la Grasserie, R. 1898. "La Catégorie psychologique de la classification revelée par le language." Revue Philosophique de la France et de l'étranger 45:594-624.

Hart, Raymond. 1963. "Semantic components of shape in Amarakaeri grammar." Anthropological Linguistics 5:1-7.

Hockett, Charles. 1958. A Course in Modern Linguistics. New York: Macmillan.

Lakoff, George. 1986. "Classifiers as a reflection of mind." In Colette Craig (ed.), Noun Classes and Categorization, pp. 13-51. Amsterdam: John Benjamins.

Levergood, Barbara. 1987. "Topics in Arusa phonology and morphology." Ph.D. dissertation, University of Texas at Austin. 
Mathiot, M. and M. Roberts. 1979. "Sex roles as revealed through referential gender in American English." In M. Mathiot (ed.) Ethnolinguistics: Boas, Sapir and Whorf Revisited, pp. 1-47. The Hague: Mouton.

Osam, Emanuel Kweku. n.d. "The death and resurrection of a noun class system - the case of Akan." Paper presented at a University of Oregon Linguistics Colloquium.

Payne, Doris L. 1987. "Noun classification in the Western Amazon." Language Sciences 65:21-44.

Payne, Doris L. 1992. "Introduction." In Doris L. Payne (ed.), Pragmatics of Word Order Flexibility, pp. 1-13. Amsterdam: John Benjamins.

Svartengren, T. H. 1927. "The feminine gender for inanimate things in AngloAmerican." American Speech 3:83-113.

Tucker, A. N. and J. Tompo Ole Mpaayei. 1955. A Maasai Grammar with Vocabulary. London: Longmans, Green and Company.

Vossen, Rainer. 1988. Towards a Comparative Study of the Maa Dialects of Kenya and Tanzania. (Nilo-Saharan 2.) Hamburg: Helmut Buske.

Department of Linguistics

University of Oregon

Eugene, OR 97403

dlpayne@oregon.uoregon.edu
[Received June 1998; accepted August 1998] 
